\title{
IDENTIFIKASI KEBUTUHAN MODAL. USAHA BERSKALA KECIL DAN MENENGAH DALAM INDUSTRI PENGOLAHAN PERIKANAN
}

\author{
Achmad Zamroni dan Agus Heri Purnomo*)
}

\begin{abstract}
ABSTRAK
Kajian ini dilaksanakan pada tahun 2004 dengan tujuan untuk mengidentifikasi kebutuhan modal berbagai usaha pengolahan perikanan dan dimaksudkan sebagai acuan ilmiah Departmen Kelautan dan Perikanan yang diperlukan untuk perencanaan dan implementasi kebijakan skim kredit permodalan. Pendekatan utama dalam kajian ini adalah analisis kelayakan dan analisis aliran kas. Sampel dipilih secara purposif dari unit-unit pengolahan ikan di berbagai kabupaten/ kota di Jawa Tengah dan Jawa Barat dengan alasan bahwa wilayah-wilayah tersebut merupakan pusat-pusat konsentrasi industri pengolahan ikan berskala kecil menengah yang menghadapi kendala permodalan. Hasil analisis menunjukkan bahwa usaha pengolahan ikan pindang, terasi, ikan asin dan ikan panggang dalam satu siklus usaha, masing-masing membutuhkan modal sebesar Rp. 11.241.500,- (ikan pindang), Rp. 32.095.500,- (terasi), Rp. 29.016.000,- (ikan asin) dan 2.757.100,- (ikan panggang). Dengan modal tersebut, masing-masing usaha dapat memperoleh keuntungan sebesar Rp. 486.000,- (ikan pindang), Rp. 94.519.500,- (terasi), Rp. 4.473.000,- (ikan asin) dan Rp. 9.720.400,- (ikan panggang). R/C yang tinggi (1,08 sampai dengan $12,79)$ menunjukkan bahwa usaha-usaha tersebut sangat berpotensi untuk dikembangkan. Untuk itu, bantuan keuangan (misalnya skim kredit lunak) layak dipertimbangkan untuk mempertahankan dan mengembangkan usaha-usaha tersebut yaitu untuk pembelian alat-alat produksi atau biayabiaya operasional.
\end{abstract}

\begin{abstract}
Identification of capital needs for small and middle scale fish processors. By: Achmad Zamroni and Agus Heri Purnomo

This study was carried out in 2004, aimed at identifying the capital needs for various fish processing units as a scientific reference for the Department of Marine Affairs and Fisheries to formulate appropriate plans of credit schemes. The primary approach used in this study was feasibility and cash flow analysis. Samples were drawn from fish processing units selected purposively from districts/cities in Central Java and West Java, considering that those locations represent the concentration of Indonesian fish processing industries. The results showed that boiled fish, fish paste, salt fish and grilled fish processing units required the amount of capital per cycle of Rp. 11.241.500, Rp. 32.095.500, Rp. 29.016.000, and 2.757.100, respectively. This, in term generates profits of $R p .486 .000, R p .94 .519 .500, R p .4 .473 .000$, and $R p .9 .720 .400$, respectively. The value of $R / C(1.08$ to 12.79$)$ indicate that these type of processing units have a potency to be developed. Therefore, financial assistance, in term of soft credit schemes could be consedered in order to maintain and develop their economic activities, e.g., through acquisition of production equipment or operational cost.
\end{abstract}

KEYWORDS: $\quad$ capital needs, fish processing, middle and small scale units

\section{PENDAHULUAN}

Usaha Kecil dan Menengah (UKM) ${ }^{1}$ di sektor perikanan, merupakan kekuatan penggerak ekonomi bagi masyarakat perikanan. Unit-unit usaha pengolahan ikan asin, ikan pindang, terasi, kerupuk ikan maupun ikan panggang adalah beberapa contoh UKM pengolahan perikanan yang selama ini dianggap sebagai penopang kehidupan masyarakat nelayan. Karena itu, UKM-UKM tersebut diharapkan tumbuh menjadi salah satu penyangga utama dalam sistem agribisnis perikanan, yang kemudian diharapkan dapat menjadi salah satu basis pertumbuhan ekonomi.
Berbagai hasil penelitian mengenai usaha kecil dan menengah (Purnomo et al., 2003 dan Ditjen PK2P, 2004), menunjukkan bahwa UKM pada umumnya mengalami kendala dalam pengembangan usahanya, kendala-kendala tersebut diantaranya terkait pada keterbatasan akses teknologi, pasar dan bahan baku, yang jika ditelusuri kesemuanya berakar dari keterbatasan modal ${ }^{2}$ usaha.

Dari sudut pandang akses pendanaan, institusi perbankan merupakan alternatif yang lebih baik dibanding pemberian modal pemerintah, yang ternyata sering tersalurkan tidak sesuai dengan kebutuhan.

\footnotetext{
-) Peneliti pada Pusat Riset Pengolahan Produk dan Sosial Ekonomi Kelautan dan Perıkanan
} 
Namun, alternatif tersebut belum dapat termanfaatkan dengan baik karena penyaluran kredit bank kepada usaha di bidang perikanan tidak semudah pemberian kredit kepada UKM sektor lain. Masalah tersebut timbul karena UKM perikanan kesulitan untuk memenuhi persyaratan formal yang ditetapkan oleh perbankan dalam hal penyaluran kredit modal. Dengan adanya kesulitan mendapatkan modal dari bank tersebut oleh pengusaha UKM mencari alternatif lain dengan cara meminjam modal uang kepada kerabat dan atau rentenir. Namun demikian, rentenir dalam sebagian besar kasus justru menjerat pengusaha UKM yaitu dalam bentuk memberikan pinjaman uang dengan bunga yang tinggi (biasanya besarnya $2 x$ bunga bank). Sehingga, tujuan pengembangan modal yang dikaitkan dengan pengembangan usaha tidak dapat tercapai.

Berdasarkan permasalahan di atas, dapat dikemukakan bahwa program-program pemerintah (Departemen Kelautan dan Perikanan, Departemen Koperasi) yang terkait dengan pemberian kredit UKM masih berpeluang dalam rangka pengembangan usaha pengolahan perikanan melalui perbaikanperbaikan pada kebijakan permodalan pemerintah. Dalam hal ini, salah satu elemen penting yang dibutuhkan untuk memperbaiki kinerja tersebut adalah ketersediaan informasi tentang besarnya kebutuhan modal bagi berbagai jenis dan skala usaha pengolahan ikan. Untuk itu, penelitian ini secara spesifik ditujukan untuk mengetahui seberapa besar kebutuhan modal yang diperlukan oleh unit-unit usaha pengolahan ikan. Informasi yang dihasilkan akan dapat digunakan sebagai bahan referensi bagi perbaikan kebijakan permodalan oleh pemerintah di sektor usaha perikanan.

\section{METODE}

\section{Kerangka Pemikiran}

Pengembangan pasar produk ikan olahan secara umum masih terbuka luas sejalan dengan semakin kuatnya budaya makan ikan dan perkembangan kebutuhan bahan makanan siap saji. Namun demikian, gejala yang ada menunjukkan bahwa keterbatasan akses modal merupakan kendala utama dalam upaya pengembangan usaha pengolahan ikan tersebut.
Keuntungan yang diperoleh para pengolah tersebut masih sangat terbatas karena tidak ada dukungan modal yang cukup. Dengan asumsi bahwa masalahmasalah lain seperti bahan baku dan pasar dapat terjamin, keberadaan modal diperkirakan dapat meningkatkan keuntungan pengusaha dan mendorong perkembangan industri pengolahan. Secara diagramatis, kerangka berpikir dapat dilihat pada Gambar 1.

\section{Metode Pengumpulan Data}

Data yang dikumpulkan dalam penelitian ini meliputi data primer dan data sekunder. Data primer meliputi data yang berkaitan dengan aspek permodalan usaha pengolahan ikan, yang meliputi nilai investasi, biaya-biaya yang dikeluarkan dan keuntungan yang diperoleh selama ini. Data sekunder diperoleh dari istansi terkait, seperti Dinas Kelautan dan Perikanan Jawa Tengah dan Jawa Barat, Kementerian Koperasi dan Usaha Kecil serta Biro Pusat Statistik.

Penelitian dilaksanakan di beberapa daerah yang menjadi pusat perikanan di Jawa Tengah, yaitu Kabupaten Tegal dan Kodya Semarang dan Jawa Barat yaitu Pelabuhan Ratu. Pengumpulan data primer difokuskan pada industri pengolahan ikan yang berskala mikro, kecil dan menengah.

Penelitian menggunakan metode survei dengan teknik wawancara langsung terhadap sumber data. Penggalian informasi mengenai usaha pengolahan ikan yang berkaitan dengan cara memperoleh bahan baku, modal usaha maupun pemasaran dilakukan wawancara langsung baik terstruktur (dengan kuesioner) maupun tidak terstruktur dengan responden. Penentuan responden dilakukan dengan metode snow ball, bahwa responden pertama ditentukan oleh pejabat Dinas Kelautan dan Perikanan setempat, kemudian responden berikutnya ditentukan oleh responden yang pertama demikian halnya responden selanjutnya.

Data diperoleh dari responden kunci (key informan) yang kemudian ditelusuri kepada responden kunci lainnya (Marzuki, 2002). Informasi tentang penyebaran usaha pengolahan ikan, diperoleh dari responden kunci yang ada di Dinas Kelautan dan Perikanan terkait untuk mengetahui pengolah ikan yang ada didaerah tersebut berdasarkan jenis usaha, yang

\footnotetext{
Berkaitan dengan penggolongan skala usaha, Biro Pusat Statistik mengkategorikan UKM yang meliputi usaha mikro dan kecil, yaitu usaha dengan omset kurang dari satu milyar rupiah. Usaha skala menengah, yaitu usaha dengan omset antara Rp. 1 hingga Rp 50 milyar (Anon., 2000)/Statistical Center Agency categorize the middle and small scale unit related to the unit scale clasification are micro and small scale unit which has less than 1 million rupiah omset and the middle scale which has range 1 to 50 billion rupiahs omset.

2 Menurut Sugiarto (2002), Modal adalah segala sesuatu yang diciptakan oleh manusia dan digunakan untuk memproduksi barang dan jasa-jasa yang mereka butuhkan/Sugiarto (2002), said that. The capital is everything that created and utilized has human to produce goods and services for their needs.
} 


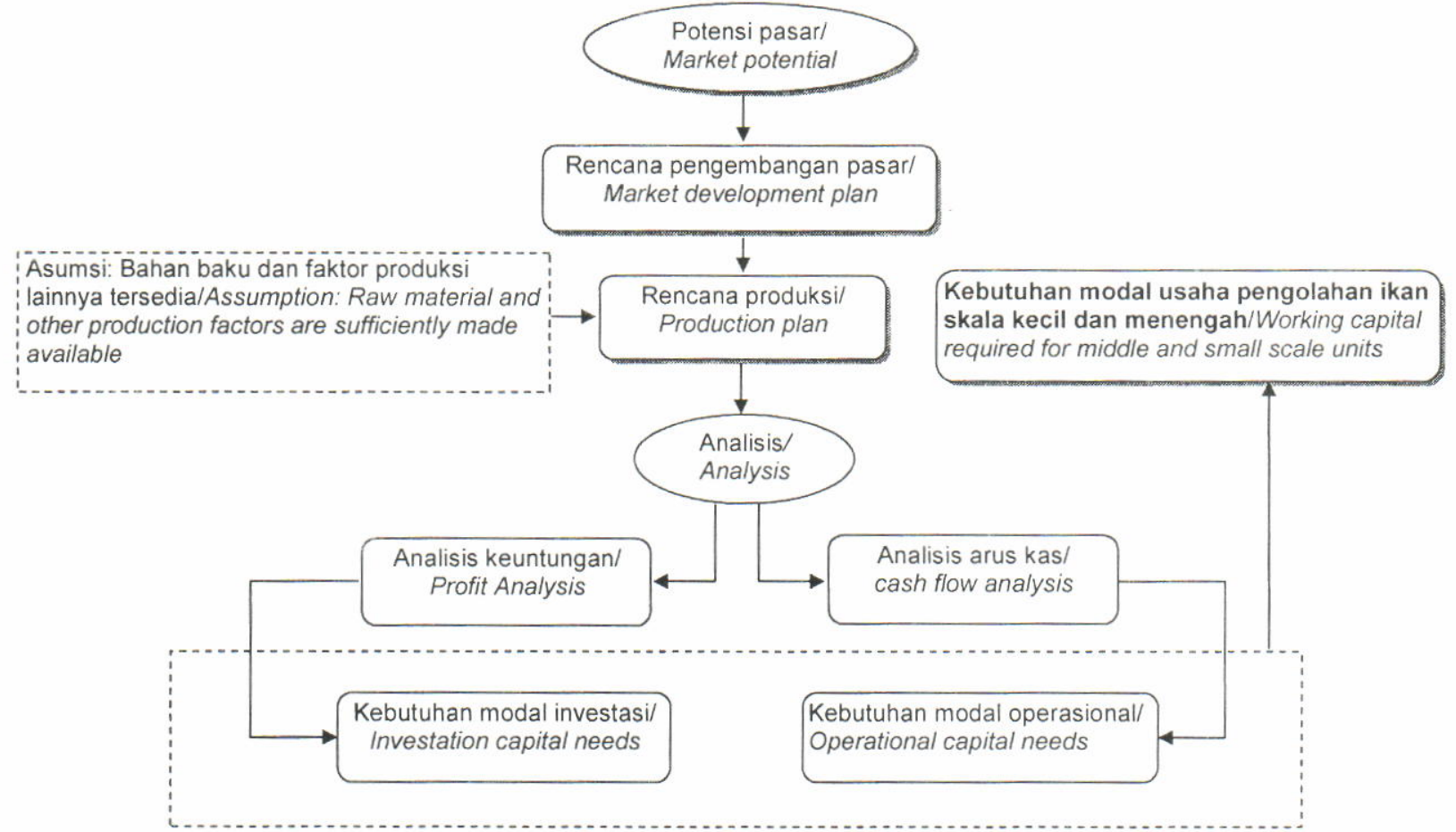

Keterangan/remark:

---- : Batasan penelitian/Scoupe of the reseach

Gambar 1. Kerangka analisis kebutuhan modal UKM pengolahan ikan.

Figure 1. Analytical framework of capital asset required small and middle scale fish processors capital need.

dapat diminta keterangan berhubungan dengan segala sesuatu mengenai usahanya. Berawal dari pengolah tersebut, kemudian dicari pengolah-pengolah lain yang sesuai dengan kebutuhan penelitian.

\section{Analisis Data}

Data terkumpul ditabulasi dan kemudian hasilnya dianalisis secara deskriptif untuk mengungkapkan gambaran usaha pengolahan ikan di Jawa Tengah dan Jawa Barat. Pada analisis usaha pengolahan ikan ini, variabel yang dianalisis adalah investasi jangka pendek serta pengeluaran atau biaya yang dikeluarkan dalam usaha tersebut dengan pendekatan keuntungan. Dari perhitungan itu, diharapkan dapat diketahui besarnya modal usaha baik modal investasi maupun modal operasional. Perhitungan besarnya biaya investasi bertujuan untuk menghitung semua kebutuhan, yang berupa peralatan-peralatan produksi serta alat-alat inventaris lainnya. Perhitungan biaya operasional digunakan untuk menghitung semua kebutuhan operasional dalam kegiatan produksi ikan olahan.
Analisis keuntungan dilakukan untuk mengetahui margin dari usaha yang diperoleh dari selisih antara pendapatan dengan biaya-biaya yang dikeluarkan (Arifin \& Fauzi, 1999).

\section{HASIL DAN BAHASAN}

\section{Potensi Pasar Produk Olahan Perikanan}

Berawal dari tingkat konsumsi ikan di Indonesia yang masih rendah ${ }^{3}$ jika dibandingkan dengan negara-negara di ASEAN bahkan di dunia, pengembangan pasar produk olahan ikan masih terbuka luas. Kalau selama ini yang menjadi andalan adalah produk perikanan yang dihasilkan melalui teknologi tinggi, maka sekarang sudah saatnya produk olahan perikanan yang dihasilkan pengolah tradisional menjadi andalan peningkatan perekonomian khususnya pengolah ikan. Terbukti ketika krisis melanda Indonesia, banyak perusahaan yang mengalami kerugian dan bangkrut, sedangkan

Konsumsi ikan perkapita di Indonesia tahun 2001 mencapai $21,7 \mathrm{~kg}$ per kapita, Jepang $110 \mathrm{~kg}$, Korea selatan $85 \mathrm{~kg}$ (BPS, 2002)/The consumption of fish per capita in Indonesian at 2001 reaching $21.7 \mathrm{~kg}$ per capita, Japan $110 \mathrm{~kg}$, South Korea 85 kg (BPS, 2002). 
sektor usaha kecil menengah (UKM) tetap bertahan dalam menjalankan usahanya.

Terlepas dari hal di atas, salah satu kendala yang dialami oleh pengolah skala mikro, kecil dan menengah adalah ketidakpastian pasar yang merupakan target penjualan. Ketidakpastian ini disebabkan oleh minimnya informasi pasar dan jaringan pasar yang dimiliki oleh pengolah tersebut. Akibat dari ketidakpastian pasar tersebut, produksi yang dihasilkan tidak selalu berkesinambungan dan cenderung fluktuatif. Akibat lainnya adalah terjadi kelebihan stock di satu daerah sementara di daerah lain terjadi kelangkaan stock. Kelebihan stock di suatu daerah memerlukan modifikasi atau diversifikasi produk, yang bertujuan untuk menghindari kejenuhankejenuhan terhadap produk yang dijual. Tetapi diversifikasi atau modifikasi produk tersebut belum berkembang di kalangan pengolah. Kecenderungan yang terjadi, para pengolah memproduksi jenis-jenis produk olahan yang harga dan kualitasnya justru lebih rendah dibandingkan mengkonsumsi ikan segar.

Kebutuhan informasi pasar dan jaringan pasar produk olahan perikanan tersebut sangat diperlukan dalam proses pengambilan keputusan secara cepat dan akurat di lingkup Departemen Kelautan dan Perikanan. Disamping itu, stakeholder pemasaran termasuk pengolah ikan sangat membutuhkan informasi tersebut untuk meningkatkan kinerja pemasaran produk olahan perikanan. Hasil pengamatan di lapang, produk ikan olahan yang berkembang di pasar di wilayah Jawa Tengah dan Jawa Barat sebagian besar bahan bakunya berasal dari laut, sebagian lagi berasal dari perikanan budidaya yaitu bandeng presto (di Semarang). Kondisi ini menyebabkan kapasitas produksi dari produk olahan ikan, sangat tergantung pada besarnya produksi penangkapan ikan yang dihasilkan oleh nelayan di setiap daerah. Ketergantungan pada setiap daerah tersebut, dikarenakan oleh akses bahan baku yaitu ikan hasil tangkapan tidak sama antara daerah satu dengan daerah yang lain. Oleh karena itu, sangat diperlukan jaringan informasi keberadaan bahan baku guna memenuhi kelangsungan usaha pengolahan ikan. Jaringan informasi ini diharapkan tidak hanya sebagai akses bahan baku saja, melainkan juga sebagai akses penjualan bagi pengolah ikan

Produksi ikan olahan di Jawa Tengah dan Jawa Barat masih mempunyai peluang untuk ditingkatkan. Salah satu peluang peningkatan tersebut ditunjukkan oleh produksi ikan hasil tangkapan di Jawa Tengah tahun 1999 sebesar 262.172 ton, pada tahun 2000 mengalami penurunan menjadi 246.514 ton dan pada tahun 2001 mengalami kenaikan menjadi 274.809 ton. Sementara produksi ikan hasil tangkapan di Jawa Barat tahun 1999 sebesar 177.183 ton, pada tahun 2000 mengalami penurunan menjadi 169.585 ton dan pada tahun 2001 juga mengalami penurunan menjadi 141.261 ton (Koeshendrajana et al., 2004). Seperti yang ditunjukkan data pada Tabel 1, produksi ikan hasil tangkapan terserap oleh industri pengolahan sebesar $100 \%$. Artinya ketersediaan bahan baku bagi industri pengolahan tersebut masih berpeluang untuk ditingkatkan lagi. Peluang lain yang mengindikasikan peningkatan produksi ikan olahan adalah adanya pasokan bahan baku ikan dari luar daerah, yang diindikasikan oleh adanya jalur-jalur pemasaran yang terjadi pada masing-masing daerah.

Potensi pasar ikan olahan seperti ikan pindang, terasi, ikan asin maupun ikan panggang, masih memiliki potensi pasar yang cukup besar. Hasil

Tabel1. Produksi perikanan tangkap menurut bentuk segar dan olahan Propinsi Jawa Tengah tahun 1999-2001

Table 1. Captured fisheries production according to fresh and processed fish in Central and West Java province, 1999-2001

\begin{tabular}{|c|c|c|c|c|c|c|c|c|}
\hline \multirow{2}{*}{ No } & \multirow{2}{*}{$\begin{array}{l}\text { Propinsi/ } \\
\text { Province }\end{array}$} & \multicolumn{3}{|c|}{$\begin{array}{l}\text { Produksi ikan segar (ton)l } \\
\text { Fresh fish production (ton) }\end{array}$} & \multicolumn{3}{|c|}{$\begin{array}{c}\text { Produksi ikan olahan (ton)/ } \\
\text { Processed fish production (ton) }\end{array}$} & \multirow{2}{*}{$\begin{array}{l}\text { Total } \\
\text { (ton) }\end{array}$} \\
\hline & & 1999 & 2000 & 2001 & 1999 & 2000 & 2001 & \\
\hline 1 & $\begin{array}{l}\text { Jawa Tengah/ } \\
\text { Central Java }\end{array}$ & 262.172 & 246.514 & 274.809 & 262.172 & 246.514 & 274.809 & 783.495 \\
\hline 2 & $\begin{array}{l}\text { Jawa Barat/ } \\
\text { West Java }\end{array}$ & 177.183 & 169.585 & 141.261 & 177.183 & 169.585 & 141.261 & 488.029 \\
\hline
\end{tabular}

Sumber/Source: Koeshendrajana et al., 2004 
pengamatan di lapang, menunjukkan bahwa produksi hasil olahan tersebut selalu habis terjual di pasar lokal dan sebagian dapat menjualnya ke luar daerah seperti ikan asin dapat dijual ke Jakarta, dan daerah lain di sekitarnya. Lain halnya di Pelabuhan Ratu, produksi ikan olahannya sebagian besar dijual untuk pasar luar daerah seperti Bogor, Jakarta, Karawang dan kotakota lain, sebagian lagi dijual di pasar lokal. Potensi pasar lokal di Pelabuhan Ratu tergolong besar, mengingat daerah ini merupakan tujuan wisata alam maupun budaya. Peluang ini belum ditangkap secara baik oleh pemerintah daerah setempat, sehingga produk-produknya seperti ikan asin dan ikan pindang banyak dijual ke Jakarta dan Bogor.

\section{Rencana Pengembangan Pasar}

Produk olahan ikan yang dihasilkan pengolah skala mikro maupun kecil sejauh ini mempunyai pangsa pasar sendiri, yaitu pada pasar-pasar tradisional di masing-masing daerah. Pasar ini biasanya memiliki konsumen yang berasal dari kelas menengah ke bawah. Menurut Purnomo et al. (2003), perkembangan pemasaran produk perikanan oleh pengusaha kecil terutama terhambat oleh rendahnya mutu ikan dan panjangnya jarak antara lokasi pemasaran dan lokasi produksi. Mutu produk yang masih tergolong rendah tersebut, mengakibatkan produk ikan olahan hanya dapat dipasarkan pada konsumen kelas bawah yang hanya mempertimbangkan atribut-atribut primer saja seperti kuantitas dan rasa, sedangkan atribut sekunder seperti nilai gizi dari produk olahan yang dihasilkan sering diabaikan.

Namun demikian, dengan memperhatikan konsumen yang akhir-akhir ini mulai cenderung memilih ikan sebagai substitusi dari daging dibandingkan dengan barang substitusi lainnya, maka pengembangan pasar dapat diarahkan kepada pasarpasar yang mempunyai konsumen kelas menengahatas. Peluang ini tentunya harus disertai dengan perbaikan mutu baik yang berkaitan dengan kualitas maupun nilai entitas produk tersebut. Pengembangan pasar ini juga dimaksudkan untuk mensejajarkan produk ikan olahan dengan produk pertanian, peternakan maupun produk olahan lainnya yang selama ini lebih dulu diakui di pasar-pasar kelas menengah-atas dalam negeri bahkan luar negeri. Keterbatasan modal yang dialami pengolah ikan skala mikro maupun kecil, saat ini telah menghambat upaya diversifikasi dan pengembangan pasar produk olahan. Produk-produk olahan yang dihasilkan selama ini hanya sebatas produk-produk yang berkualitas rendah. Kualitas ini berkaitan dengan tingkat kebersihan dan tampilan produk yang hanya mampu dijual di pasar-pasar tradisional.
Upaya pengembangan pasar harus tetap mempertahankan 'pasar' yang sudah ada, caranya adalah dengan memanfaatkan jaringan pasar yang dibentuk secara individu maupun mengikuti jaringan yang telah dibentuk oleh teman sesama pengolah atau pedagang seperti yang selama ini dilakukan. Cara seperti ini sering disebut dengan 'nitip dagangan', yaitu pengolah menitipkan dagangan kepada pengolah lain yang memasarkan ke wilayah pemasarannya sedang pengolah yang dititipkan tersebut hanya memperoleh keuntungan seperti yang telah disepakati sebelumnya. Cara seperti ini hampir terjadi di seluruh lokasi penelitian, karena ada sebagian lagi yang menjual produknya sendiri. Pengolah yang ini adalah pengolah yang cukup mempunyai dana untuk memasarkan. Produk yang mereka pasarkan berbeda-beda, ada yang memasarkan dalam bentuk bahan setengah jadi dan ada juga dalam bentuk produk akhir (end product). Contoh produsen yang memasarkan bahan setengah jadi adalah pengolah terasi yang menjual rebon halus untuk bahan terasi. Sampai saat ini, pengolah tersebut telah memenuhi permintaan beberapa produsen terasi baik di Jawa Tengah maupun di Jawa Timur, seperti Pati, Rembang, Tuban dan Lamongan. Bahan terasi setengah jadi dari Tegal (Sidodadi) mempunyai keunggulan dari rasa dan kandungan proteinnya, yang mempunyai ciri dan karakteristik yang dapat membedakan dengan produk dari daerah lain. Contoh pengolah yang menjual dalam bentuk end product adalah produsen baso ikan jangilus dari Pelabuhan Ratu, ikan panggang dari Semarang, ikan pindang dari Pati dan Tegal dan krupuk ikan dari Tegal. Pengolah/produsen tersebut masing-masing mempunyai pangsa pasar sendirisendiri, baik di dalam daerah maupun di luar daerah.

Perluasan atau membentuk pangsa pasar baru di luar kota merupakan langkah selanjutnya ketika langkah pertama sudah dilakukan dan atau bersamaan dengan langkah yang pertama. Langkah yang kedua ini biasanya dilakukan dengan agak berspekulasi. Dianggap berspekulasi karena di daerah pamasaran yang baru, biasanya telah ada produk olahan yang sejenis dan mereka harus bersaing dengan produk olahan yang sudah ada. Namun demikian, langkah spekulasi ini diimbangi oleh pengolah ikan yang melihat peluang pasar dengan mempertimbangkan strategi 'perubahan tempat'. Misalnya ikan asin, ikan pindang dan terasi akan mempunyai nilai lebih jika dipasarkan ditempat-tempat yang jauh dari pantai (daerah pegunungan). Contoh pada penelitian ini, produk-produk ikan olahan yang berasal dari Tegal, Semarang dan Pati sering dipasarkan di Kebumen, Yogyakarta, Ambarawa dan daerah sekitarnya. Proses membuka 'pasar' yang baru tidak bisa dilakukan dengan cara 'nitip dagangan' 
tetapi dengan cara promosi yang dilakukan sendiri dengan catatan disertai dengan perbaikan mutu produk.

\section{Rencana Produksi}

Selama ini yang menjadi penyebab pengolah ikan skala mikro, kecil dan menengah memproduksi ikan olahan adalah latar belakang mereka yang dulunya menjadi nelayan. Pada saat berhenti berprofesi sebagai nelayan, mereka mengalihkan usahanya sebagai pengolah ikan. Tetapi pekerjaan mengolah ikan tersebut sudah dilakukan istri mereka pada saat masih menjalani pekerjaan sebagai nelayan. Faktor usia merupakan salah satu yang mendorong para nelayan beralih pekerjaan.

Melihat kemampuan penyediaan bahan baku ikan hasil tangkapan di Jawa Tengah dan Jawa Barat seperti yang disajikan dalam Tabel 1, kemampuan produksi pengolahan ikan skala mikro, kecil dan menengah dapat ditingkatkan minimal $25 \%$ dengan asumsi semua kebutuhan modal baik yang digunakan untuk pembelian bahan baku dan biaya pemasaran dapat tercukupi atau bisa teratasi ditambah asumsiasumsi lain yaitu harga barang dan peralatan yang mendukung produksi dianggap tetap atau tidak mengalami hambatan. Nilai prosentase di atas diambil dengan melihat produksi perikanan tangkap dalam rentang waktu 3 tahun (1999-2001) seperti pada Tabel 1 dapat terserap pada industri pengolahan ikan.

Kekuatan produksi di setiap daerah berbeda-beda, tergantung jumlah persediaan bahan baku. Misalnya di Pati, persediaan bahan baku adalah sejumlah $56.880,37$ ton (tahun 2003). Dengan produksi ikan olahan, untuk ikan pindang rata-rata per tahun adalah 3000 ton, ikan asin 4.000 ton/th, ikan panggang 1.700 ton/th, terasi 0,17 ton/th. Jumlah bahan baku di atas secara matematis telah melebihi produksi ikan olahan yang dihasilkan, kelebihan tersebut akan dijual ke luar daerah. Berbeda dengan keadaan di Pelabuhan Ratu, pada tahun 2002 produksi ikan jangilus yang menjadi andalan produk olahan sebesar 351,16 ton sedangkan ikan tongkol 662,76 ton. Namun demikian, dengan jumlah tersebut pengolah skala mikro dan kecil masih merasa kekurangan bahan baku untuk memproduksi ikan olahan seperti baso, ikan asin dan ikan pindang. Kekurangan ini bisa diatasi dengan supply bahan baku dari cold storage, baik yang ada di Jakarta maupun di Pelabuhan Ratu sendiri. Demikian halnya di Semarang, meskipun persediaan bahan baku yang pada waktu-waktu tertentu terkadang dirasa kurang, namun kondisi ini bisa ditanggulangi dengan keberadaan 'pasar kobong' yang merupakan pusat penjualan bagi produk perikanan, baik yang berbentuk segar maupun olahan yang berasal dari seluruh wilayah Jawa Tengah.

\section{Analisa Finansial Usaha Pengolahan Ikan}

Pengolahan ikan merupakan salah satu sub sistem industri perikanan. Dalam rangka mengetahui besarnya keuntungan dan biaya-biaya yang dikeluarkan, maka dilakukan suatu analisis finansial usaha pengolahan. Analisis ini dimulai dengan melakukan identifikasi semua komponen yang mendukung berlangsungnya usaha pengolahan ikan. Oleh karena adanya keterbatasan yang dihadapi dalam analisis usaha, maka kegiatan analisis dilakukan dengan menggunakan asumsi-asumsi yang berkaitan dengan biaya-biaya seperti pada Tabel 2 . Asumsi tersebut meliputi: jumlah hari dan bulan kerja, jumlah produk yang dihasilkan, harga produk serta harga bahan baku, besar bunga bank dan lamanya siklus.

Masing-masing usaha dalam melakukan analisis usaha menggunakan asumsi jumlah hari kerja selama satu bulan adalah 25 hari dalam 8 bulan setahun. Produksi rata-rata per hari diasumsikan sebesar 1 ton untuk ikan pindang, 1,5 ton untuk terasi, $274 \mathrm{~kg}$ untuk ikan asin dan 1,5 ton untuk ikan panggang. Asumsi bunga bank sebesar $16 \%$ dan harga bahan baku masing-masing produk adalah Rp. 5.000,-; Rp. 3.000,; Rp. 5.000-15.000,-; dan Rp. 4.500,- dengan harga jual produk masing-masing adalah $\mathrm{Rp} 5.000,-; \mathrm{Rp}$. 16.000; Rp. 16.500 dan Rp. 7.000,-. Dalam 25 hari kerja dalam sebulan, agar target produksi dapat terpenuhi dalam pengolahan ikan pindang, harus tersedia bahan baku ikan tongkol segar sebesar 20 ton, sedangkan rebon untuk pengolahan terasi harus tersedia 0,1 ton. Pada pengolahan ikan asin diperlukan bahan ikan jangilus dan ikan lainnya sebesar 0,8 ton, sedangkan untuk pengolahan ikan panggang membutuhkan bahan baku ikan manyung sebanyak 3,75 ton.

Keseimbangan atau efisiensi antara biaya-biaya yang dikeluarkan untuk memproduksi dengan hasil yang akan diperoleh dapat tercapai jika kekuatan pasar sudah jelas. Usaha dikatakan menguntungkan jika besarnya penerimaan lebih besar dibandingkan dengan biaya-biaya yang dikeluarkan. Jika yang terjadi sebaliknya, maka secara finansial usaha akan mengalami kerugian. Total biaya dihitung per bulan berdasarkan kebutuhan produksi yang meliputi biaya tetap dan biaya tidak tetap masing-masing usaha (ikan pindang, terasi, ikan asin dan ikan panggang) adalah Rp. 115.961.917,- ; Rp.130.479.504,-; Rp. 92.341.306,- dan Rp. 20.519.257,- . Pendapatan yang diterima oleh pengolah setiap bulannya dari hasil penjualan masing-masing produk adalah Rp.125.000.000,-- (ikan pindang), Rp.600.000.000,(terasi); Rp.113.025.000,- (ikan asin) dan Rp. 262.500.000,- (ikan panggang). Namun demikian, 
Tabel2. Asumsi-asumsi yang digunakan analisis usaha pengolahan ikan

Table 2. Asumption used to feasibility analysis of fish processing units

\begin{tabular}{|c|c|c|c|c|c|}
\hline No & $\begin{array}{c}\text { Asumsi/ } \\
\text { Asumption }\end{array}$ & $\begin{array}{l}\text { Ikan pindang/ } \\
\text { Boiled fish }\end{array}$ & $\begin{array}{l}\text { Terasi/ } \\
\text { Fish paste }\end{array}$ & $\begin{array}{l}\text { Ikan asin/ } \\
\text { Salt fish }\end{array}$ & $\begin{array}{l}\text { Ikan panggang/ } \\
\text { Grilled fish }\end{array}$ \\
\hline 1 & $\begin{array}{l}\text { Jumlah hari kerja per bulan/ } \\
\text { Working days per month }\end{array}$ & $\begin{array}{l}25 \text { Hari/ } \\
25 \text { days }\end{array}$ & $\begin{array}{l}25 \text { Hari/ } \\
25 \text { days }\end{array}$ & $\begin{array}{l}25 \text { Hari/ } \\
25 \text { days }\end{array}$ & $\begin{array}{l}25 \text { Hari/ } \\
25 \text { days }\end{array}$ \\
\hline 2 & $\begin{array}{l}\text { Jumlah bulan kerjal } \\
\text { Working month per year }\end{array}$ & $\begin{array}{l}8 \text { bulan } / 8 \\
\text { month }\end{array}$ & $\begin{array}{l}8 \text { bulan/ } \\
8 \text { month }\end{array}$ & $\begin{array}{l}8 \text { bulan/ } \\
8 \text { month }\end{array}$ & $\begin{array}{l}8 \text { bulan/ } \\
8 \text { month }\end{array}$ \\
\hline 3 & $\begin{array}{l}\text { Jumlah produksi rata-rata perhari/ } \\
\text { Average production quantity per day }\end{array}$ & $1000 \mathrm{~kg}$ & $1500 \mathrm{~kg}$ & $274 \mathrm{~kg}$ & $1500 \mathrm{~kg}$ \\
\hline 4 & $\begin{array}{l}\text { Harga bahan baku/ } \\
\text { Raw material price }(R p / k g)-(I D R / k g)\end{array}$ & 5,000 & 3,000 & $5.000-15.000$ & 4,500 \\
\hline 5 & $\begin{array}{l}\text { Harga jual produk/ } \\
\text { Product price }(R p / k g)-(I D R / k g)\end{array}$ & 5,000 & 16,000 & 16,500 & 7,000 \\
\hline 6 & $\begin{array}{l}\text { Bunga Bank/ } \\
\text { Rate }\end{array}$ & $16 \%$ & $16 \%$ & $16 \%$ & $16 \%$ \\
\hline 7 & 1 siklus usaha/Production cycles & 1 hari & 5 hari & 5 hari & 1 hari \\
\hline
\end{tabular}

hasil perhitungan ke empat usaha tersebut masingmasing memperoleh keuntungan yaitu $\mathrm{Rp}$. 9.038.083,-; Rp.469.520.496,-; Rp. 20.683.694,- dan Rp. 241.980.743,--. Perhitungan RC-ratio usaha pengolahan ikan pindang, terasi, ikan asin dan ikan panggang, masing-masing sebesar 1,$08 ; 4,60 ; 1,22$ dan 12,79. Melihat hasil tersebut, dapat dikatakan bahwa ke empat usaha tersebut layak untuk dikembangkan, mengingat hasil $R C$-rationya lebih dari 1. Secara lengkap, analisa usaha pengolahan ikan skala kecil dan menengah dapat dilihat pada Tabel 3.

Mereka (pengolah ikan) di atas, bisa memperoleh keuntungan usaha dengan nilai $R / C$ yang tinggi. Hasil tersebut, disamping menunjukkan kelayakan usahanya, juga menunjukkan bahwa pengolah ikan di atas mempunyai potensi sekaligus peluang untuk mengembangkan usahanya. Namun demikian, ada kendala-kendala yang berkaitan dengan tekologi pengolahan, bahan baku serta pemasaran yang terkait dengan persediaan modal, contohnya teknologi pengasapan ikan dan pengeringan, pembelian bahan baku dan biaya pemasaran.

Namun demikian, dalam pengembangan usaha, pengolah harus selalu mempertimbangkan aspek efisiensi biaya yang dikeluarkan. Artinya biaya yang dikeluarkan harus didasarkan pada skala prioritas terhadap faktor-faktor produksi yang gunakan.

\section{Kebutuhan Modal Usaha Pengolahan Ikan}

Besarnya kebutuhan modal usaha pengolahan ikan per siklus produksi berasal dari besarnya jumlah investasi ditambahkan biaya operasional per siklus produksi. Perhitungan-perhitungan analisis usaha pengolahan ikan telah diuraikan hasilnya seperti yang dijelaskan pada Tabel 3 dan besarnya modal yang dihasilkan masing-masing usaha pengolahan ikan setiap siklus produksi adalah Rp. 11.241.500,(ikan pindang), Rp. 32.095.500,- (terasi), Rp. 29.016.000,- (ikan asin) dan Rp. 2.757.100,- (ikan panggang). Perhitungan tersebut didasarkan asumsi bahwa siklus usaha masing-masing usaha adalah 1 hari, 5 hari, 5 hari dan 1 hari, dengan biaya operasional Rp. 4.514.000,- (ikan pindang), Rp. 25.480.500,- (terasi), Rp. 18.132.000,- (ikan asin) dan Rp. 779.600,- (ikan panggang), usaha-usaha tersebut dapat memperoleh keuntungan sebesar Rp. 486.000,(ikan pindang), Rp. 94.519.500,- (terasi), Rp. 4.473.000,- (ikan asin) dan Rp. 9.720.400,-. Uraian secara tabulatif mengenai kebutuhan modal usaha ditunjukkan pada Tabel 4. Hasil ini menunjukkan secara jelas kemungkinan keuntungan yang didapatkan dari biaya yang dikeluarkan sebagai modal masing-masing usaha pengolahan ikan skala kecil dan menengah.

Permasalahan utama yang dihadapi oleh usaha mikro kecil dan menengah adalah minimnya 
Tabel 3. Analisa usaha pengolahan ikan skala kecil dan menengah per bulan di Jawa Tengah dan Jawa Barat tahun 2004

Table 3. Financial analysis of the middle and small scale units per month in Central and West Java, 2004

\begin{tabular}{|c|c|c|c|c|c|c|}
\hline No & $\begin{array}{c}\text { Uraian/ } \\
\text { Description }\end{array}$ & $\begin{array}{l}\text { Satuan/ } \\
\text { Units }\end{array}$ & $\begin{array}{l}\text { Usaha ikan } \\
\text { pindang/ } \\
\text { Boiled fish } \\
\text { unit }\end{array}$ & $\begin{array}{c}\text { Usaha } \\
\text { terasi/ } \\
\text { Fish paste } \\
\text { unit }\end{array}$ & $\begin{array}{l}\text { Usaha ikan } \\
\text { asin/ } \\
\text { Salt fish } \\
\text { unit }\end{array}$ & $\begin{array}{c}\text { Usaha Ikan } \\
\text { panggang/ } \\
\text { Grilled fish } \\
\text { unit }\end{array}$ \\
\hline A & Investasi/Investment & & & & & \\
\hline 1 & $\begin{array}{l}\text { Sewa tempat/ } \\
\text { Land rent }\end{array}$ & $\begin{array}{l}\text { Rupiah/bln/ } \\
\text { IDR/month }\end{array}$ & 62.500 & 100.000 & 125.000 & 100.000 \\
\hline \multirow[t]{2}{*}{2} & $\begin{array}{l}\text { Sarana produksi/ } \\
\text { Equipment production }\end{array}$ & $\begin{array}{l}\text { Rupiah/bln/ } \\
\text { IDR/month }\end{array}$ & 6.665 .000 & 6.515 .000 & 10.759 .000 & 1.877 .500 \\
\hline & $\begin{array}{l}\text { Jumlahl } \\
\text { Sub total }\end{array}$ & Rupiah-IDR & 6.727 .500 & 6.615 .000 & 10.884 .000 & 1.977 .500 \\
\hline B & Biaya tetap/Fixed cos & & & & & \\
\hline 1 & $\begin{array}{l}\text { Penyusutan/ } \\
\text { Depreciation }\end{array}$ & Rupiah-IDR & 111.917 & 77.004 & 181.306 & 29.257 \\
\hline \multirow[t]{2}{*}{2} & $\begin{array}{l}\text { Biaya investasi/ } \\
\text { Investment cost }\end{array}$ & Rupiah-IDR & 3.000 .000 & 3.000 .000 & 1.500 .000 & 1.000 .000 \\
\hline & $\begin{array}{l}\text { Jumlahl } \\
\text { Sub total }\end{array}$ & Rupiah-IDR & 3.111 .917 & 3.077 .004 & 1.681 .306 & 1.029 .257 \\
\hline C & Biaya tidak tetap/Vari & able cost & & & & \\
\hline 1 & $\begin{array}{l}\text { Bahan baku/ } \\
\text { Raw material }\end{array}$ & Rupiah-IDR & 100.000 .000 & 120.000 .000 & 67.200 .000 & 16.875 .000 \\
\hline 2 & $\begin{array}{l}\text { Tenaga kerja/ } \\
\text { Labour }\end{array}$ & Rupiah-IDR & 750.000 & 4.800 .000 & 14.000 .000 & 1.250 .000 \\
\hline 3 & $\begin{array}{l}\text { Perawatan/ } \\
\text { Maintenance }\end{array}$ & Rupiah-IDR & 500.000 & 1.000 .000 & 100.000 & 500.000 \\
\hline 4 & $\begin{array}{l}\text { Bahan penunjang/ } \\
\text { Supporting material }\end{array}$ & Rupiah-IDR & 3.750 .000 & 1.177 .500 & 510.000 & 345.000 \\
\hline 5 & $\begin{array}{l}\text { Transportasi/ } \\
\text { Transportation }\end{array}$ & Rupiah-IDR & 7.500 .000 & 250.000 & 7.500 .000 & 500.000 \\
\hline \multirow[t]{2}{*}{6} & Lain-lain/Others & Rupiah-IDR & 350.000 & 175.000 & 1.350 .000 & 20.000 \\
\hline & $\begin{array}{l}\text { Jumlah/ } \\
\text { Sub total }\end{array}$ & Rupiah-IDR & 112.850 .000 & 127.402 .500 & 90.660 .000 & 19.490 .000 \\
\hline D & $\begin{array}{l}\text { Biaya total per } \\
\text { bulan/Total cost } \\
(b+c) \text { per month }\end{array}$ & Rupiah-IDR & 115.961 .917 & 130.479 .504 & 92.341 .306 & 20.519 .257 \\
\hline$E$ & $\begin{array}{l}\text { Penerimaan/ } \\
\text { Benefit }\end{array}$ & Rupiah-IDR & 125.000 .000 & 600.000 .000 & 113.025 .000 & 262.500 .000 \\
\hline $\mathrm{F}$ & $\begin{array}{l}\text { Keuntungan/ } \\
\text { Profit }\end{array}$ & Rupiah-IDR & 9.038 .083 & 469.520 .496 & 20.683 .694 & 241.980 .743 \\
\hline G & $\begin{array}{l}\text { Golongan skala } \\
\text { usaha/Classification o } \\
\text { units }\end{array}$ & f scale & $\begin{array}{l}\text { Usaha } \\
\text { kecil }\end{array}$ & Usaha kecil & $\begin{array}{l}\text { Usaha } \\
\text { kecil }\end{array}$ & Usaha kecil \\
\hline $\mathrm{H}$ & $\mathrm{RC}$ ratio & & 1.08 & 4.60 & 1.22 & 12.79 \\
\hline
\end{tabular}


Tabel 4. Kebutuhan modal usaha per siklus produksi yang diperlukan masing-masing produk olahan Table 4. The capital needed per cycles for every product processing

\begin{tabular}{|c|c|c|c|c|c|}
\hline No & $\begin{array}{c}\text { Uraian/ } \\
\text { Description }\end{array}$ & $\begin{array}{c}\text { Ikan } \\
\text { pindang/ } \\
\text { Boiled fish } \\
\text { (Rp-IDR) }\end{array}$ & $\begin{array}{c}\text { Terasi/ } \\
\text { Fish paste } \\
\text { (Rp-IDR) }\end{array}$ & $\begin{array}{l}\text { Ikan asin/ } \\
\text { Salt fish } \\
\text { (Rp-IDR) }\end{array}$ & $\begin{array}{c}\text { Ikan } \\
\text { panggang/ } \\
\text { Grilled fish } \\
\text { (Rp-IDR) }\end{array}$ \\
\hline 1 & $\begin{array}{l}\text { Biaya investasi/ } \\
\text { Investment cost }\end{array}$ & 6.727 .500 & 6.615 .000 & 10.884 .000 & 1.977 .500 \\
\hline 2 & $\begin{array}{l}\text { Biaya operasional per siklus/ } \\
\text { Operational cost per cycles }\end{array}$ & 4.514 .000 & 25.480 .500 & 18.132 .000 & 779.600 \\
\hline 3 & $\begin{array}{l}\text { Modal dalam per siklus } \\
\text { usaha/Capital per cycles }\end{array}$ & 11.241 .500 & 32.095 .500 & 29.016 .000 & 2.757 .100 \\
\hline 4 & $\begin{array}{l}\text { Penerimaan dalam } 1 \text { siklus/ } \\
\text { Revenue/benefit per cycles }\end{array}$ & 5.000 .000 & 120.000 .000 & 22.605 .000 & 10.500 .000 \\
\hline 5 & Keuntungan/Profit per cycles & 486.000 & 94.519 .500 & 4.473 .000 & 9.720 .400 \\
\hline
\end{tabular}

ketersediaan modal yang digunakan untuk pembelian persediaan bahan baku dan kebutuhan biaya pemasaran. Sedangkan kehadiran teknologi pengolahan, bedasarkan pengamatan di lapangan belum begitu berpengaruh terhadap kelangsungan usaha pada sebagian unit pengolahan ikan. Seperti yang diuraikan bahwa usaha pengolahan ikan pindang di Pelabuhan Ratu dan terasi di Tegal sangat membutuhkan tambahan modal untuk keperluan biaya operasional atau biaya produksi. Besarnya modal seperti yang disebutkan di atas merupakan kebutuhan minimal, artinya besarnya modal tersebut hanya untuk menutupi kekurangan biaya yang membuat pengolah mengalami titik impas dan diasumsikan belum memperoleh keuntungan tetapi tidak mengalami kerugian. Kondisi tersebut dengan asumsi ketersediaan bahan baku baik harga maupun jumlah bahan baku serta pangsa pasar selalu stabil dan tidak mengalami fluktuasi yang signifikan.

Selain ikan pindang di Pelabuhan Ratu dan terasi di Tegal, usaha lain yang tergantung dengan ketersediaan bahan baku adalah fillet ikan, ikan asin, ikan panggang (Tegal), ikan panggang (Semarang) dan ikan asin (Pelabuhan Ratu). Kehadiran teknologi pengolahan ikan sangat dibutuhkan pada pengolahan krupuk ikan dan ikan asin, yaitu teknologi untuk proses pengeringan. Teknologi ini dibutuhikan ketika terjadi musim penghujan, karena usaha tersebut selama ini sangat tergantung pada panas sinar matahari untuk mengeringkan produk yang akan dihasilkan. Dengan adanya teknologi pengeringan ini akan membantu dalam mengatasi pengeringan produk, dan keberadaan teknologi tersebut tidak terlalu mempengaruhi ketersediaan modal yang dimiliki oleh pengolah seperti pada saat belum ada teknologi tersebut.

Namun demikian, kehadiran teknologi pengolahan juga tergantung pada besarnya usaha. Hal ini disebabkan, pangsa pasar dari produk ikan olahan seperti ikan asin, terasi, ikan pindang dan ikan panggang masih pada skala tradisional. Misalnya pada pengolahan ikan panggang di Semarang, idealnya usaha ini dapat menggunakan teknologi pengasapan yang bisa memproduksi ikan panggang lebih banyak pada setiap siklus produksi. Alat bantuan yang diberikan pemerintah kepada beberapa pengolah yaitu berupa tempat pengasapan beserta cerobong asap dapat membantu pengolah dalam memenuhi permintaan ikan panggang. Hambatan yang dialami oleh pengolah ikan, ketika mereka bermaksud membeli/mengadakan alat pemanggang tersebut secara mandiri. Pengolah belum mampu membelinya, karena satu set alat pengasapan/pemanggang tersebut diperkirakan mencapai Rp. 5 juta rupiah. Kebutuhan teknologi ini bukan merupakan faktor utama dalam peningkatan produksi karena jumlah produksi juga sangat dipengaruhi dengan besarnya pasar yang mampu menyerap produksi yang dihasilkan dan besarnya ketersediaan bahan baku.

\section{KESIMPULAN}

Usaha pengolahan ikan pindang, terasi, ikan asin dan ikan panggang dalam satu siklus usaha, masingmasing membutuhkan modal sebesar Rp. 11.241.500,- untuk produksi ikan pindang, Rp. 
32.095.500,-untuk produksi terasi, Rp. 29.0196.000,untuk produksi ikan asin dan Rp. 2.757.100,- untuk produksi ikan panggang. Besarnya modal tersebut dapat memberi keuntungan masing-masing kepada usaha pengolahan ikan pindang, terasi, ikan asin dan ikan panggang sebesar Rp. 486.000,-; Rp. 94.519.500,-; Rp. 4.473.000,- dan Rp. 9.720.400,-. Besarnya $R C$-ratio masing-masing usaha adalah 1,08 ; 4,$60 ; 1,22$ dan 12,79 . Nilai tersebut menunjukkan bahwa masing-masing usaha pengolahan ikan yang dimaksud layak untuk dikembangkan. Perhitungan finansial di atas, dapat membantu para pengolah ikan terutama yang berskala kecil untuk merencanakan usahanya, agar tercapai hasil yang optimal. Pemanfaatan teknologi pengolahan yang terjangkau oleh masyarakat sangat diperlukan dalam mendukung keberhasilan usaha baik secara personal maupun kolektif.

Peran pemerintah dalam hal ini dapat berupa pemberian skim kredit berupa penyediaan teknologi pengolahan ikan yang sesuai dengan kemampuan finansial pengolah ikan. Skim kredit tersebut berupa angsuran lunak yang nantinya dapat dilakukan secara bergulir kepada pengolah-pengolah ikan lainnya.

\section{DAFTAR PUSTAKA}

Anonimous, 2000. Statistik Usaha Kecil Menengah. Biro Pusat Statistik. Jakarta.

Ditjen PK2P, 2004. Strategi Peningkatan Konsumsi Ikan di Indonesia. Buku Rencana Unggulan Strategi
Peningkatan Konsumsi Ikan di Indonesia. Direktorat Jenderal Peningkatan Kapasitas Kelembagaan dan Pemasaran. Departemen Kelautan dan Perikanan 2004. p. 11-14. 56.

Arifin, J. dan Fauzi, A. 1999. Aplikasi Exel dalam Aspek Finansial Studi Kelayakan Proyek. PT. Elex Media Komputindo. Jakarta. 85 pp.

BPS. 2002. Pengeluaran untuk Konsumsi Penduduk Penduduk Indonesia (Expenditure for Consumption of Indonesia). Buku 1. Badan Pusat Statistik, Jakarta, Indonesia.

Koeshendrajana, S., Purnomo, A.H. dan Nasution, Z (ed.). 2004. Indikator Kinerja Sektor Kelautan dan Perikanan "Volume I: Produksi, Distribusi dan Konsumsi; Perikanan Tangkap". PRPPSE. BRKP Jakarta. 550 pp.

Marzuki. 2002. Metodologi Riset. Bagian Penerbitan Fakultas Ekonomi Univeritas Islam Indonesia Yogyakarta. $122 \mathrm{pp}$.

Purnomo, A.H., Reswati, E., Hikmah, Hikamayani, Y. 2003. Pengembangan Industri Perikanan di Kawasan Berperanan Ekologis Penting. Laporan Teknis Pusat Riset Pengolahan Produk dan Sosial Ekonomi Kelautan dan Perikanan Tahun 2003.

Purnomo, A.H., Suryawati, S.H., Hikmayani, Y. dan Reswati, E. 2003. Model Pengembangan Industri Perikanan Terpadu: (Studi Kasus di Wilayah Pengembangan Utama III, Jawa Tengah). Jurnal Penelitian Perikanan Indonesia. Edisi Sosial Ekonomi. 9 (6) p. 35-56.

Sugiarto, 2002. Ekonomi Mikro "Sebuah Kajian Komprehenshif". PT. Gramedia Pustaka Utama. Jakarta. 514 pp 